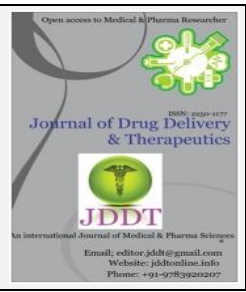

Open $\odot$ Access

Research Article

\title{
Formulation and Evaluation of Teneligliptin and Telmisartan Bilayer Tablets for the Treatment of Coexistent Type II Diabetes Mellitus and Hypertension
}

\author{
Lodha Gaurav S. ${ }^{*}$, Dr. Chemate Satyam Z. ${ }^{2}$ \\ ${ }^{1}$ Department of Pharmaceutics, Dr. Vithalrao Vikhe Patil Foundation's, College of Pharmacy, Vilad Ghat, Ahmednagar (MS), India-414111.
}

${ }^{2}$ Head of Department of Pharmaceutics, Dr. Vithalrao Vikhe Patil Foundation's, College of Pharmacy, Vilad Ghat, Ahmednagar (MS), India414111.

\begin{abstract}
In the current scenario type two diabetes mellitus and hypertension have become prevalent in large number of population. But there are many patients which are suffering from Type II Diabetes Mellitus as well as hypertension. Such condition is called co-existent Type II Diabetes Mellitus and Hypertension. In the present work an attempt is made to treat co-existent type II Diabetes Mellitus and hypertension by formulating a Bilayer tablet of Teneligliptin and Telmisartan. Both drugs are sustained released to give a day long relief to the patients and to also reduce the dose frequency. Both the layers of the tablets were formulated by wet granulation method. The granules were tested for angle of repose, bulk density, tapped density, compressibility and Hausner's ratio to check their efficacy. Eleven different types of formulations were made using various polymers and excipients with the drugs such as PVP K30, HPMC K4M, Starch, Crospovidone, Lactose, Mannitol, Talc and Magnesium Stearate. From these 11 formulations F6 showed better tablet characteristics and drug release rate than other formulations. Thus F6 is the best formulation in this study. Biological screening of the drugs combination of Teneligliptin and Telmisartan was also done to check the presence of antidiabetic activity of the combination which showed positive results.
\end{abstract}

Keywords: - Teneligliptin, Telmisartan, Sustained, Bilayer.

Article Info: Received 08 July 2019; $\quad$ Review Completed 17 August 2019; $\quad$ Accepted 24 August 2019; Available online 15 Sep 2019

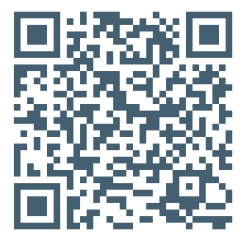

Cite this article as:

Lodha GS, Chemate SZ, Formulation and Evaluation of Teneligliptin and Telmisartan Bilayer Tablets for the Treatment of Coexistent Type II Diabetes Mellitus and Hypertension, Journal of Drug Delivery and Therapeutics. 2019; 9(5):26-38 http://dx.doi.org/10.22270/jddt.v9i5.3537

Address for Correspondence:

Lodha Gaurav S., Dr. Vithalrao Vikhe Patil Foundation's, College of Pharmacy, Vilad Ghat, Ahmednagar (MS), India - 414111.

Email: gauravlodha769@gmail.com

\section{INTRODUCTION:}

In this modern world of faster and hectic lives, eating healthy and staying fit is ignored. Such ignorance may lead to various harmful diseases and disorders. Diabetes mellitus is such kind of disorder which if not managed properly may prove fatal. Type II Diabetes mellitus is the most harmful type of diabetes as the body of the patient becomes insulin resistant. Also hypertension is present in large number of populations. But when these two severe diseases are present coexistently in an individual, additional care is needed to be taken. Coexistent Type Two Diabetes Mellitus (TTDM) and hypertension exposes patients to severe co-morbidities.

Hypertension (HTN) is present in more than $50 \%$ of patients with diabetes mellitus (DM) and contributes significantly to both micro and macrovascular disease in DM. Indeed, the risk for cardiovascular disease (CVD) is four-fold higher in patients with both DM and HTN as compared to the normotensive non-diabetic controls. To this point, a meta-analysis of 102 prospective studies involving 698,782 individuals found that DM is responsible for approximately a two-fold increased risk for coronary heart disease, stroke and deaths from cardiovascular cause, including heart failure, cardiac arrhythmia, hypertensive disease, etc. In developed countries 60-65\% prevalence is seen in coexistent type II diabetes mellitus and hypertension. Complex polypharmacy suggested by international organizations leads to the increased pill burden and decreased patient compliance which leads to worsening of conditions ${ }^{1,2}$.

Hence there is a need for a combination of antidiabetic and antihypertensive drugs for the treatment of coexistent type two diabetes mellitus and hypertension. 


\section{MATERIALS:-}

Teneligliptin was provided as gift sample from Lupin Pharmaceuticals Limited, Pune whereas Telmisartan was obtained from Abbott Healthcare Pvt. Ltd. Himachal Pradesh as gift samples. Polymers and excipients such as HPMC K4M, PvpK30, crospovidone, talc etc were purchased from JP. Fine chemicals and Loba Chemise Pvt. Ltd.

\section{METHODS:-}

Various techniques can be used to formulate bilayer tablets. Wet granulation is one of the techniques used to formulate the two layers of tablets. Wet granules of both layers are formulated individually. Wet granulation techniques have various advantages. Hence it is a method of choice for many tablet formulations. It enhances the flow properties of powder mix. It avoids segregation of powder components during tabletting or storage. It also reduces cross-contamination and hazard associated with the generation of toxic dust that may arise during manufacturing process. Wet granulation not only improves the compression characteristics of drug substances as well as improves the appearance of the final product. Wet granulation involves use of water for granulation. Aqueous binder solution is added to the dough mass and then sieved to produce the required size of granules. Tablets made from wet granulation techniques have better hardness and appearance then directly compressed tablets. Conventional equipment, commonly available excipients and a limited number of processing steps are involved in direct compression. Also high doses can be accommodated. Moreover this technique improves the dissolution characteristics of the poorly water-soluble drugs by allowing uniform distribution of the binder that acts as a wetting agent and enable adequate wetting of the drug substance during granulation. It also increases the chances of adequate and uniform contact between the drug and hydrophilic polymer for better dissolution. These improved granule characteristics also results in even erosion of tablets during dissolution $(4,15)$.

\section{$>\quad$ Preparation of Tablet by Wet Granulation :}

- Wet Granulation of Sustained Release Telmisartan Layer :-

Wet granulation is the most widely used to prepare tablets. Formulation with different binders was compressed into tablets. The required quantities of Telmisartan ,starch ,lactose monohydrate ,HPMC K4M, crospovidone were weighed accurately using analytical balance and were mixed well using laboratory conditions. The aqueous binder solution was added and mixed thoroughly to form dough mass. Carmiosine Colour was added to the aqueous binder solution for Telmisartan granules to provide visual detection of two different layers in the bilayer tablets. The formed mass was passed through Mesh no.12 to obtain wet granules .The wet Granules were dried in a hot air oven at $300 \mathrm{c}$ temperatures. then the dried granules were passed through mesh no.16 to break aggregates. Talc \& magnesium stearate were passed through mesh no.100 on to dry granules and blended in a polyethylene bag.The Tablet granules were then compressed using compression machine at punch No. $5(11,15)$.

\section{- Wet Granulation of Sustained Release} Teneligliptin Layer :-

Wet granulation is done for this layer of Bilayer tablet too. This layer consists of drug/API. Teneligliptin(20mg) and various excipients which act as binders, diluents and lubricants in the formulation. These are starch, mannitol and magnesium stearate respectively. HPMC K4M is the sustained releasing agent. The aqueous binder solution was added and mixed thoroughly to form a dough mass. The formed dough mass was passed through Mesh no.12 to obtain wet granules of Teneligliptin layer. The wet granules were dried in a hot air oven at $300{ }^{\circ} \mathrm{C}$ temperatures. On drying, the dried granules were passed through mesh no.16 to break aggregates if formed. Talc \& magnesium stearate were passed through mesh no.100 on to dry granules and blended in the polyethylene bag kept for these granules. The Tablet granules were then compressed using compression machine at punch No. 5 over the Telmisartan layer.

Thus, The Bilayer Tablet is formed by the Above Mentioned Processes

\section{Compositions of Bilayer Tablets}

Table No.1: Compositions of Sustained Release Layer of Teneligliptin :-

\begin{tabular}{|c|c|c|c|c|c|c|c|c|c|c|c|c|}
\hline $\begin{array}{l}\text { Sr. } \\
\text { No. }\end{array}$ & Ingredient mg/Tablet & F1 & F2 & F3 & F5 & F4 & F6 & F7 & F8 & F9 & F10 & F11 \\
\hline 1 & Teneligliptin & 20 & 20 & 20 & 20 & 20 & 20 & 20 & 20 & 20 & 20 & 20 \\
\hline 2 & HPMC K4M & 105 & 105 & 105 & 105 & 53 & 105 & 105 & 105 & 105 & 105 & 105 \\
\hline 3 & PVP K30 & 20 & 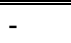 & - & 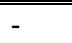 & - & - & - & - & - & 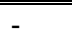 & - \\
\hline 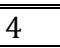 & Starch & 55 & 55 & 55 & 82 & 55 & 82 & 82 & 55 & 55 & 55 & 55 \\
\hline 5 & Lactose & 34 & 54 & - & 27 & 106 & $\begin{array}{c}- \\
\end{array}$ & 07 & $\begin{array}{c} \\
\end{array}$ & 444 & 34 & 24 \\
\hline 6 & Mannitol & 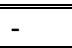 & 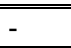 & 54 & 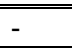 & - & 27 & - & 34 & - & 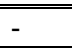 & - \\
\hline 7 & Crosspovidone & 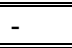 & 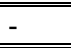 & 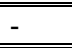 & 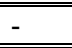 & 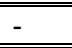 & 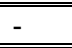 & 20 & 20 & 10 & 20 & 30 \\
\hline 8 & Magnesium Stearate & 3 & 3 & 3 & 3 & 3 & 3 & 3 & 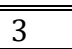 & 3 & 3 & 3 \\
\hline 9 & Talcum & 3 & 3 & 3 & 3 & 3 & 3 & 3 & 3 & 3 & 3 & 3 \\
\hline 10 & P. Water & Q.S. & Q.S. & QS & QS & Q.S & QS. & QS. & QS & Q.S & Q.S & Q.S \\
\hline & Total Weight & 240 & 240 & 240 & 240 & 240 & 240 & 240 & 240 & 240 & 240 & 240 \\
\hline
\end{tabular}


Table No.2 : Compositions of Sustained Release Layer of Telmisartan :-

\begin{tabular}{|c|c|c|c|c|c|c|c|c|c|c|c|c|}
\hline $\begin{array}{l}\text { Sr. } \\
\text { No. }\end{array}$ & $\begin{array}{l}\text { Ingredient } \\
\text { mg/Tablet }\end{array}$ & F1 & F2 & F3 & $\overline{F 4}$ & F5 & F6 & F7 & F8 & F9 & F10 & F11 \\
\hline 1 & Telmisartan & 40 & 40 & 40 & 40 & 40 & 40 & 40 & 40 & 40 & 40 & 40 \\
\hline 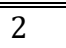 & "HPMC K4M & 105 & 105 & 105 & 53 & 105 & 105 & 157 & 105 & 105 & 105 & 105 \\
\hline 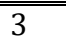 & PVP K30 & 40 & - & - & - & - & - & - & - & - & 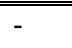 & - \\
\hline 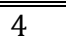 & Starch & 255 & 255 & 55 & 55 & 27 & 27 & 27 & 27 & 55 & 255 & 55 \\
\hline 5 & Lactose & 14 & 54 & 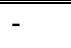 & 106 & 82 & 62 & 10 & - & 44 & 34 & 24 \\
\hline 6 & Mannitol & 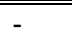 & - & 54 & - & - & - & - & 62 & - & 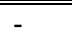 & 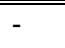 \\
\hline$\overline{77}$ & "Crosspovidone & 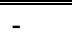 & 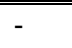 & 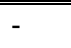 & - & 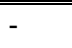 & 20 & 20 & 20 & 10 & 20 & 30 \\
\hline 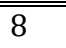 & "Magnesium Stearate & 3 & 3 & 3 & 3 & 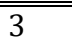 & 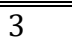 & 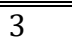 & $\overline{3}$ & 3 & 3 & 3 \\
\hline 9 & Talcum & 3 & 3 & 3 & 3 & 3 & 3 & 3 & 3 & 3 & 3 & 3 \\
\hline \multirow[t]{2}{*}{10} & P. Water & Q.S. & Q.S. & Q.S. & Q.S. & Q.S. & Q.S. & Q.S. & Q.S. & Q.S. & Q.S. & Q.S. \\
\hline & Total Weight & 260 & 260 & 260 & 260 & 260 & 260 & 260 & 260 & 260 & 260 & 260 \\
\hline
\end{tabular}

Total Weight of Each Bilayer Tablet was Thus 500mg for All prepared Formulations.

\section{- Pre-Compression Characteristics $(2,4,7,8)$ :}

The following parameters are determined.

\section{Angle of Repose:}

The angle of repose has been used to characterize the flow properties of solids. This is the maximum angle possible between surface of pile of powder or granules and the horizontal plane.

\section{Bulk Density}

The ratio of mass (weight) to volume is known as the bulk density of material. The bulk density is obtained by dividing the weight of the sample in grams by final volume in $\mathrm{cm}^{3}$.

\section{Tapped Density}

Tapped density is determined by placing a graduated cylinder containing a known mass of drug on a mechanical tapper apparatus which is operated for fixed number of taps $(\sim 100)$ until a powder bed volume has reached the minimum.

\section{Compressibility Index}

The compressibility index of the powder was determined by Carr's index. The Carr's index is determined from the tapped density and poured density (bulk density) as per its formula.

\section{Hausner's Ratio}

Hausner's ratio is determined from the ratio of tapped density to bulk density using its standard formula.

\section{$>$ Evaluation of Post Compression Parameter:}

\section{1) General Appearance:}

General appearance would include a number of aspects like size, shape, odor, taste, texture, legibility and identifying marks.

\section{2) Size and Shape:}

Different shapes and size of tablet are available in the market they are manufactured in order. The shape and size of a tablet would vary based on tooling used in the tablet manufacturing. In laboratory scale tablet size measured by the Vanier caliper. Tablet thickness should be controlled within $\pm 5 \%$ variation of a standard value.

\section{3) Hardness:}

Tablet hardness and strength are the essential to see that the tablet can with the shock and stress during manufacturing packaging and transportation, and while handle by the patient. For each formulation, the hardness of tablet determined using the Monsanto hardness tester.

\section{4) Friability:}

Friability is the test for a tablet those whether the tablet is stable to abrasion or not, it is tested by using Roche Friabilitor.

\section{5) Weight Variation:}

Weight variation test is performed to check that the manufactured tablets have a uniform weight. For a tablet to pass the test not more than 2 tablets should lie out of the specified percentage and if no tablet differ by more than two times the percentage limit.

Table No. 3: Standard Limits for Weight Variation as per I.P.

\begin{tabular}{|l||l||l|}
\hline Sr. No. & $\begin{array}{l}\text { Average weight of } \\
\text { Tablet (mg) }\end{array}$ & $\begin{array}{l}\text { Maximum Percentage } \\
\text { difference allowed }\end{array}$ \\
\hline \hline 1 & 80 & 10 \\
\hline \hline 2 & $80-250$ & 7.5 \\
\hline \hline 3 & $>250$ & 5 \\
\hline
\end{tabular}

Table No.4: Standard Limits for Weight Variation as per USP

\begin{tabular}{|l||l||l||}
\hline Sr. No. & $\begin{array}{l}\text { Average weight of } \\
\text { Tablet (mg) }\end{array}$ & $\begin{array}{l}\text { Maximum Percentage } \\
\text { difference allowed }\end{array}$ \\
\hline \hline 1 & $130 /$ Less & 10 \\
\hline \hline 2 & $130-324$ & 7.5 \\
\hline \hline 3 & $>324$ & 5 \\
\hline
\end{tabular}




\section{6) Drug Content $(2,15,16)$ :}

From each batch 3 tablets were weighed each containing 10 mg of tablet were taken. Tablets were triturated in motor and quantity of powder equivalent to $10 \mathrm{mg}$ of tablet powder was transferred to $100 \mathrm{ml}$ volumetric flask. Sufficient quantity of Phosphate buffer solution $\mathrm{P}^{\mathrm{H}} 6.8$ was added with shaking and volume was made up to the mark and filtered through whatman filter paper. Further dilutions were made in concentration $2,4,6,8,10 \mathrm{ug} / \mathrm{ml}$. then absorbance was recorded at different wavelength of drugs such as (Teneligliptin at $243.6 \mathrm{~nm}$ and Telmisartan at $295 \mathrm{~nm}$ ) against phosphate buffer solution $\mathrm{P}^{\mathrm{H}} 6.8$ as a blank.

\section{7) In vitro Disintegration Time (6,14):}

In vitro disintegration time of the tablet was determined using USP disintegration test apparatus as per I.P. specifications. It is determined by using USP device which consisted of 6 glass tubes that are 3 inches long. Open at one end and held against 10 mesh screen at the bottom end of basket rack assembly. To test for disintegration time, one tablet is placed in each tube and the basket arch is positioned in a 1 liter basket assembly up and down. To compliance with the USP standard, all tablet must disintegrate and all particles must pass through the 10 mesh in the time specified. $(56,58)$

\section{8) In vitro Dissolution Study $(15,18)$ :}

Dissolution profiles of bilayer tablets were determined using the USP method II with paddle speed at $50 \mathrm{rpm}$. The media used in dissolution apparatus was phosphate buffer $\mathrm{P}^{\mathrm{H}} 6.8$ $(900 \mathrm{ml})$ and maintained it at $37 \pm 10 \mathrm{C}$. the $2 \mathrm{ml}$ of sample were withdrawn at $0,30,60,90,120,180,240,300,360$, 420 minutes time intervals.. $5 \mathrm{ml}$ diluted with $10 \mathrm{ml}$ of phosphate buffer solution, and analyzed at $243.6 \mathrm{~nm}$ and $295 \mathrm{~nm}$ using UV-Visible double beam spectrophotometer (JASCO V-630).

Table No.5 : Procedure for Dissolution Study

\begin{tabular}{|l||l||}
\hline Parameters & Conditions \\
\hline \hline Dissolution media & $\begin{array}{l}\text { 900ml of phosphate buffer } \\
\text { solution } \mathrm{PH} 6.8\end{array}$ \\
\hline \hline Temperature & $37 \pm 1^{0} \mathrm{C}$ \\
\hline \hline RPM & 50 \\
\hline \hline Drug Content & $\begin{array}{l}\text { Weigh of tablet equivalent to } \\
500 \mathrm{mg}\end{array}$ \\
\hline \hline Volume Withdrawn & $2 \mathrm{ml}$ \\
\hline \hline Volume made up to & $10 \mathrm{ml}$ \\
\hline \hline$\Lambda$ max & $243.6 \mathrm{~nm}$ and 295nm. \\
\hline \hline Dilution Factor & 5 \\
\hline \hline
\end{tabular}

\section{9) Stability Study:}

ICH recommends carrying out stress testing on the drug substance to establish its inherent characteristics and support the solubility of the proposed analytical procedure. Stability study at room temperature is the method of determining the actual shelf life of the product. Unfortunately it is difficult to make an accurate expiration date prediction until 2-3 yrs. Of data are generated, which will require long shelf life conditions. Hence accelerated stability studied were carried out at elevated temperature will help to determine shelf life within a lesser period of time. The prepared tablets were evaluated for a period of one to three month as per ICH Guidelines. (58)

\section{Biological Screening:}

A] Antidiabetic Activity-

Experimental Procedure: The compounds extracted during the present work were subjected to alloxan induced antidiabetic activity.

\section{Requirements-}

Standard drug: - Metformin Hydrochloride $(120 \mathrm{mg} / \mathrm{kg}$ p.o. body weight in $0.25 \%$ CMC solution)

Test Combinations $(19,20,23)$ :-

\section{The Test combinations are taken as :}

1) Teneligliptin :- $0.01 \mathrm{mg} / \mathrm{kg}$ p.o + Telmisartan $1 \mathrm{mg} / \mathrm{kg}$ p.o. in $0.25 \% \mathrm{MC}$ solution,

2) Teneligliptin :- $0.1 \mathrm{mg} / \mathrm{kg}$ p.o + Telmisartan $1 \mathrm{mg} / \mathrm{kg}$ p.o. in $0.25 \% \mathrm{MC}$ solution,

3) Teneligliptin :- $1 \mathrm{mg} / \mathrm{kg}$ p.o + Telmisartan $1 \mathrm{mg} / \mathrm{kg}$ p.o. in $0.25 \%$ MC solution

Chemicals:-Alloxan monohydrate(150mg/kg i.p.)

Apparatus: - Glucometer, Disposable syringe (1ml tuberculin syringe), feeding needles (for oral dose), Polypropylene cage.

\section{Procedure-}

Wistar rats either sex weighing between 150-200gm were used. The animals were housed under controlled conditions with standard diet and water. The animals were kept fasted for $24 \mathrm{hrs}$ with water, diabetes was induced by Alloxan monohydrate $(120 \mathrm{mg} / \mathrm{kg}$ i.p) in normal saline solution.

A 5\% dextrose solution was given in feeding bottle for a day to overcome early hypoglycemic phase. The blood glucose level was monitored by taking blood tail tip cut method on glucometer.

After $72 \mathrm{hrs}$,the animals showing blood glucose level beyond $150 \mathrm{mg} / \mathrm{dl}$ were segregated and were divided into 3 groups.viz...(i) vehicle treated group (ii) standard treated group, (iii) drug treated group comprised 5 subgroups for 3 test combinations. Each group as well as subgroup comprised of 6 animals.The doses of combination of Teneligliptin and Telmisartan to be administered to wistar rats based on the available references of individual drugs was calculated. (for acute study).

\section{B] Blood Sample Collection From Tail Vein:-}

1) Prevent the animal by using the mechanical restraint device with the tail of the animal protruding. Use antiseptic solution to clean the area; do not rub back and forth to prevent

degradation of quality of sample. Prevent the tail from moving with non-dominant hand and rotate $1 / 4$ turn to work on the lateral tail vein. 2) Align the needle parallel to the tail with the sloping edge of the needle to be used facing up. Insert needle into the tail vein starting at the tip of the tail (distally) i. Gently aspirate it to collect by syringe; ii. Observe blood flash by syringe insertion and let the blood drip from needle hub into collection tube or into hematocrit tube by capillary action; iii. Remove the inserted needle from the vein and collect blood droplets in the collection tube or into hematocrit tube by capillary action. 3) Put gentle pressure with the help of gauze for just 15 to 30 seconds until 
bleeding from the vein has stopped. If the blood does not stops, clotting agent can be used to stop the blood flow. 4) Throw or dispose the needle well. If the animal is administered with an anesthetia, monitor the animal till it is fully awake and it is able to move normally. Repetitive bleeds for blood collection may be performed by insertion of the needle further up the tail.

\section{C] Methodology:-Collection of Blood:-}

Table no. 6 Biological activity profile table (A1, B1, C1 are doses of Teneligliptin and A2, B2, C2 are doses of Telmisartan respectively.

\begin{tabular}{|c|c|c|c|}
\hline Sr.No. & $\begin{array}{l}\text { Groups } \\
(\mathrm{N}=6)\end{array}$ & Treatment and dose day & Observation \\
\hline 1 & Group-I & Vehicle control( $1 \mathrm{ml}$ saline water p.o.) 0 to 28 day. & \multirow{6}{*}{$\begin{array}{l}\text { 1) Estimation of } \\
\text { blood glucose level on } \\
2^{\text {nd }}, 4^{\text {th }}, 6^{\text {th }}, 8^{\text {th }}, 10^{\text {th }} \text { and } \\
28^{\text {th }} \text { days. } \\
\text { 2) Stastistical analysis } \\
\text { by ANOVA followed by } \\
\text { Dunnett's test. }\end{array}$} \\
\hline 2 & Group-II & Negative control Alloxan monohydrate(150mg/kg i.p.) for 0 to 2 days & \\
\hline 3 & Group-III & $\begin{array}{l}\text { Positive control Alloxan Monohydrate }(150 \mathrm{mg} / \mathrm{kg}) \text { for } 2 \text { days }+ \\
\text { Metformin hydrochloride }(50 \mathrm{mg} / \mathrm{kg}) \text { p.o. for next } 26 \text { days. }\end{array}$ & \\
\hline 4 & Group-IV & $\begin{array}{l}\text { Alloxan monohydrate }(150 \mathrm{mg} / \mathrm{kg}) \text { i.p.+ test drugs } \mathrm{A} 1(0.1 \mathrm{mg} / \mathrm{kg})+ \\
\text { A2(1mg/kg) p.o. }\end{array}$ & \\
\hline 5 & Group-V & $\begin{array}{l}\text { Alloxan monohydrate }(150 \mathrm{mg} / \mathrm{kg}) \text { i.p+ test drugs } \mathrm{B} 1(1 \mathrm{mg} / \mathrm{kg})+ \\
\text { B2 }(1 \mathrm{mg} / \mathrm{kg}) \text { p.o }\end{array}$ & \\
\hline 6 & Group-VI & $\begin{array}{l}\text { Alloxan monohydrate }(150 \mathrm{mg} / \mathrm{kg}) \text { i.p+ test drugs } \mathrm{C} 1(10 \mathrm{mg} / \mathrm{kg})+ \\
\text { C2 }(1 \mathrm{mg} / \mathrm{kg}) \text { p.o. }\end{array}$ & \\
\hline
\end{tabular}

\section{RESULTS AND DISCUSSION:}

\section{IR Spectroscopy Analysis:}

- The IR Spectrum of the drug agrees with its chemical structure 6-chloro-4hydroxy-2-methyl-N-2-pyridyl-2H-thieno-[2, 3

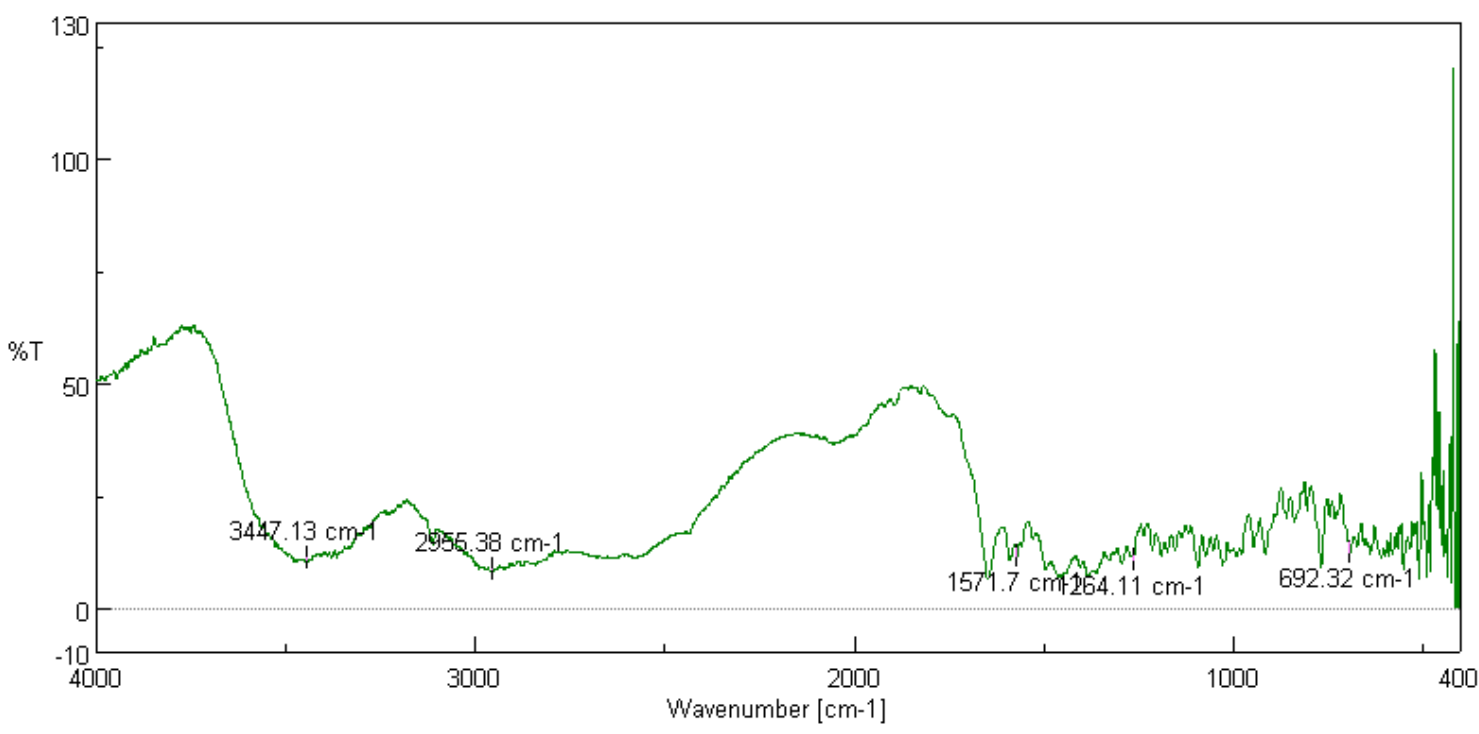

Figure No. 1: Infrared Spectrum of Teneligliptin

Table No. 7: IR Peak Value of Teneligliptin

\begin{tabular}{|l|l||l|l||}
\hline Sr. No. & $\begin{array}{l}\text { Absorption } \\
\text { Peak cm-1 }\end{array}$ & $\begin{array}{l}\text { Attributed to } \\
\text { Functional Group }\end{array}$ & Type of Vibrations \\
\hline \hline & 3447.13 & N-H & Stretching \\
\hline \hline & 2956.87 & C-H & Stretching \\
\hline \hline & 1571.7 & C-C & Stretching \\
\hline \hline & 692.32 & C-S & Stretching \\
\hline
\end{tabular}


The IR Spectrum of the drug agree with the chemical structure (RS)-2-(3-benzoylphenyl)-propionic acid.

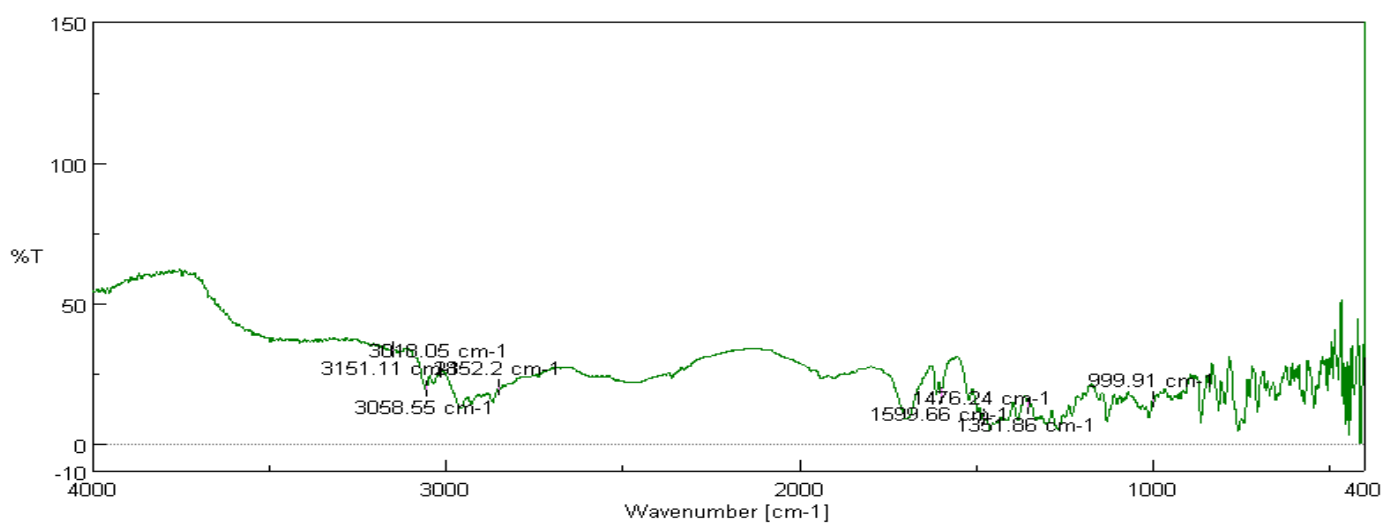

Figure No.2: Infrared Spectrum of Telmisartan

Table No. 8: IR Peak Value of Telmisartan

\begin{tabular}{|l||l||l||l||}
\hline $\begin{array}{l}\text { Sr. } \\
\text { No. }\end{array}$ & $\begin{array}{l}\text { Absorption Peak } \\
\text { cm }^{-1}\end{array}$ & $\begin{array}{l}\text { Attributed to } \\
\text { Functional Group }\end{array}$ & Type of Vibrations \\
\hline \hline & 3151.11 & C-H & Stretching \\
\hline \hline & 1476.24 & C $=\mathrm{C}$ & Stretching \\
\hline & 999.91 & C-N & Stretching \\
\hline
\end{tabular}

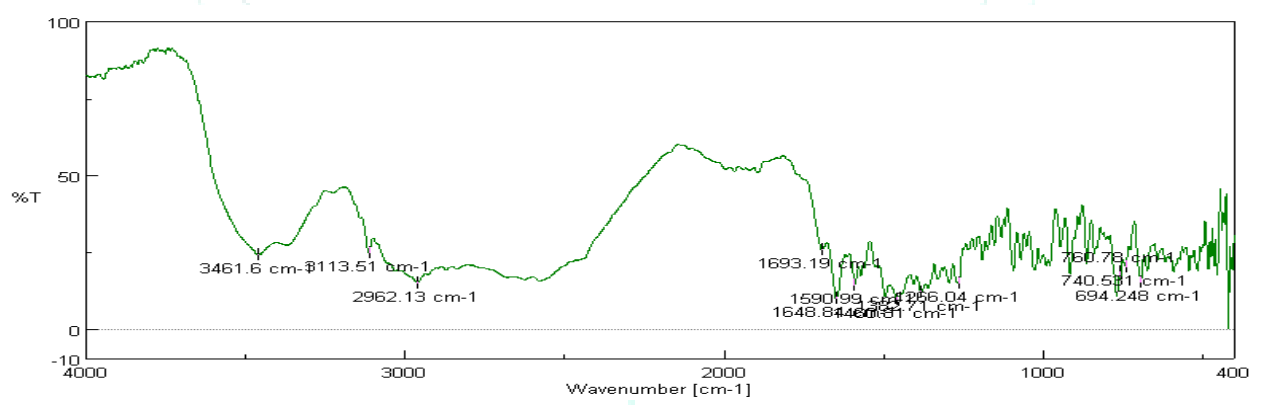

Figure No. 3: IR Spectrum of Teneligliptin and Telmisartan Mixture with Polymers

Table No. 9: IR Value of Teneligliptin and Telmisartan Mixture with Polymers

\begin{tabular}{||l||l||}
\hline Types of Bonds & $\begin{array}{l}\text { Wave Number } / \mathbf{c m}^{-1} \\
\text { Found }\end{array}$ \\
\hline N-H Stretching & 3456.78 \\
\hline \hline C-H Stretching (Methyl) & 2970.8 \\
\hline \hline C-H Stretching Vibration of (aromatic ring) & 3114.47 \\
\hline \hline C=O Stretching Vibration of Amide Moiety & 1650.77 \\
\hline \hline Aliphatic C-H Stretch & 2962.13 \\
\hline \hline CH2 (Bending) & 1461.78 \\
\hline C=C Stretching/bending & 1599.66 \\
\hline \hline COOH bending & 1381.75 \\
\hline \hline COOH Acid & 1696.09 \\
\hline \hline Disubstituted benzene & 741.496 \\
\hline \hline C-N Stretching & 758.852 \\
\hline \hline C-S & 1265.07 \\
\hline
\end{tabular}

The peaks observed in pure samples of Teneligliptin and Telmisartan drugs sample determined by IR analysis are one and same as the reference graph. The peaks observed in the IR graph of the mixture sample of Teneligliptin and telmisartan with the polymers which are used in the formulation are in same position / state as that of the IR Spectrum of pure sample.
Thus justified that there is no or minimal interaction of binders with the drug molecules. Hence there is no obstacle in using these binders to formulate the tablet.

\section{Differential Scanning Calorimetry:}

The DSC thermogram of Teneligliptin showed a sharp exothermic peak at $210.6^{\circ} \mathrm{C}$. Telmisartan exhibited single, 
sharp endothermic peak at $275.6^{\circ} \mathrm{C}$. The obtained values are much close to reported value of Teneligliptin and Telmisartan Melting Point. The Teneligliptin and telmisartan bilayer Tablet Formulation exhibited double, sharp endothermic peaks at $355.43^{\circ} \mathrm{C}, 260.73^{\circ} \mathrm{C}$ and $170.91^{\circ} \mathrm{C}$.

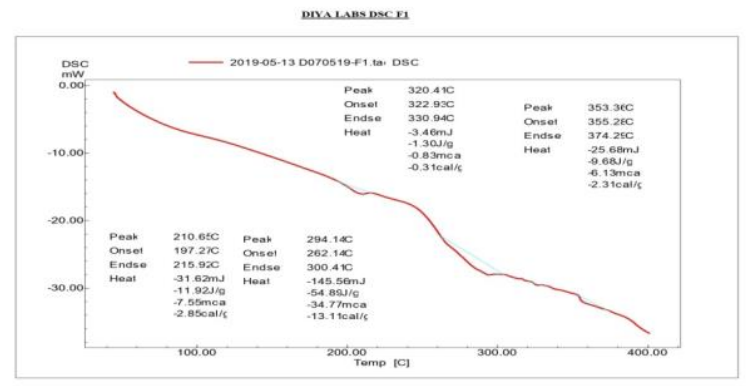

Figure No. 4: DSC Graph of Teneligliptin

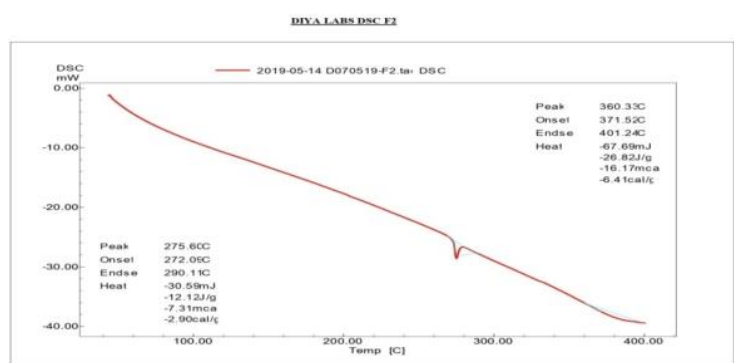

Figure No. 5: DSC Graph of Telmisartan

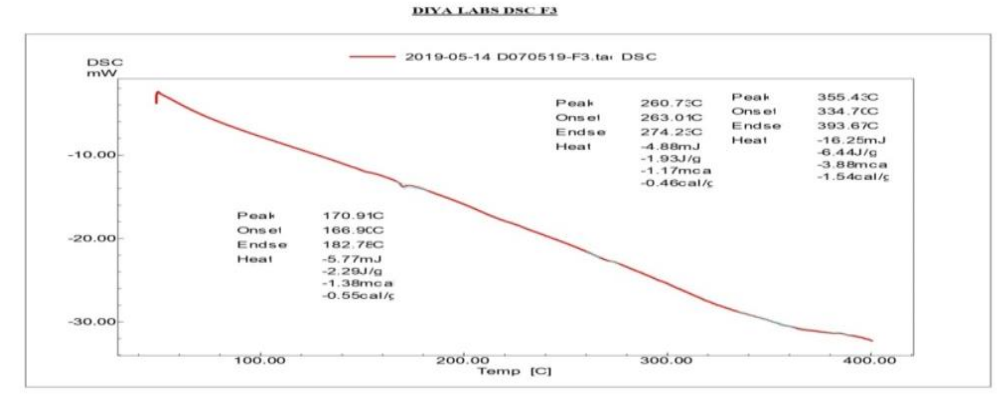

Figure No. 6: DSC Graph of Teneligliptin and Telmisartan Bilayer Tablet Formulation

\section{Calibration Curve of Teneligiptin:}

The standard calibration curve shows the slope of 0.065 and correlation coefficient of 0.998 . The curve was found to be linear in the concentration range of $2,4,6,8,10 \mu \mathrm{g} / \mathrm{ml}$ at $243.6 \mathrm{~nm}$. The calculation of drug content, in vivo dissolution study was based on the calibration curve.

Table No. 10: Calibration Curve of Teneligliptin

\begin{tabular}{|l||l|l||}
\hline \hline $\begin{array}{l}\text { Sr. } \\
\text { No. }\end{array}$ & $\begin{array}{l}\text { Concentration } \\
(\boldsymbol{\mu g} / \mathbf{m l})\end{array}$ & $\begin{array}{l}\text { Absorbance at } \\
\mathbf{2 4 3 . 6} \mathbf{~ n m}\end{array}$ \\
\hline \hline & 0 & 0 \\
\hline \hline & 10 & 0.1991 \\
\hline \hline & 20 & 0.3871 \\
\hline \hline & 30 & 0.5928 \\
\hline \hline & 40 & 0.7876 \\
\hline \hline & 50 & 0.9578 \\
\hline
\end{tabular}

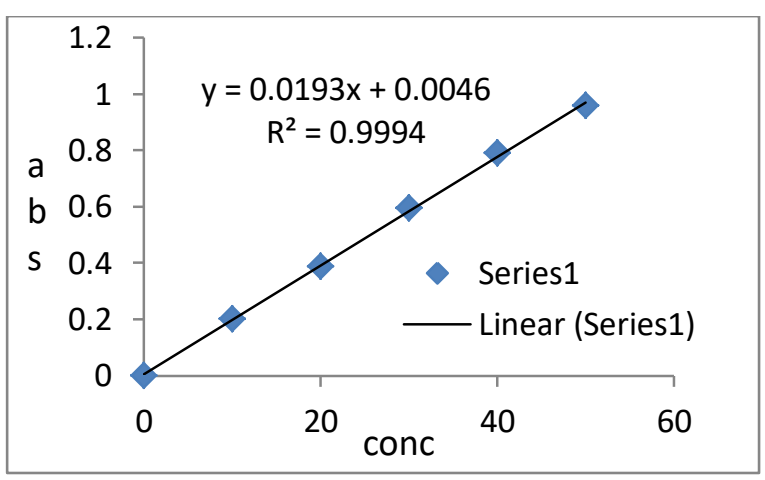

Figure No. 7: Calibration Curve of Teneligliptin

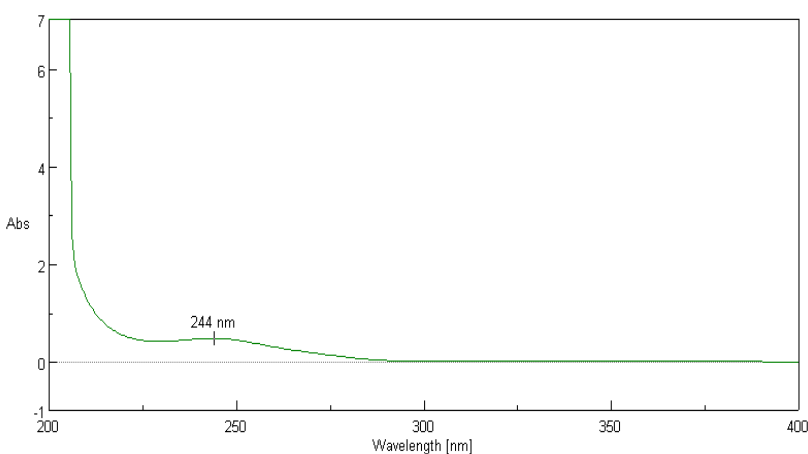

Figure No. 8: UV Spectrum of Teneligliptin

Tablet No. 11: UV Parameter for calibration curve in pH 6.8 buffer solution

\begin{tabular}{|l||l|l||}
\hline $\begin{array}{l}\text { Sr. } \\
\text { No. }\end{array}$ & Parameters & $\begin{array}{l}\text { Value in pH 6.8 } \\
\text { phosphate } \\
\text { solution }\end{array}$ \\
\hline \hline 1 & $\begin{array}{l}\text { Absorbance } \\
\text { maximum }(\lambda \max ) \text { in } \\
\text { nm }\end{array}$ & $243.6 \mathrm{~nm}$ \\
\hline \hline 2 & Slope & 0.0193 \\
\hline \hline 3 & Intercept & 0.0046 \\
\hline \hline 4 & $\begin{array}{l}\text { Correlation } \\
\text { Coefficient }\end{array}$ & 0.9994 \\
\hline \hline 5 & Equation & $\mathrm{Y}=0.0193 \mathrm{X}+0.0046$ \\
\hline
\end{tabular}




\section{Calibration Curve of Telmisartan:}

The standard calibration curve of Telmisartan was obtained by plotting Absorbance vs. Concentration. Table No. 12 shown the absorbance values of Telmisartan. The standard curve is shown in Figure 9.9. The standard calibration curve shows the slope of 0.075 and correlation coefficient of 0.996 . The curve was found to be linear in the concentration range of $2,4,6,8,10 \mu \mathrm{g} / \mathrm{ml}$ at $295 \mathrm{~nm}$. The calculation of drug content, in vivo dissolution study was based on the calibration curve.

Table No. 12: Calibration Curve of Telmisartan

\begin{tabular}{|l||l||l||}
\hline Sr. No. & Concentration $(\boldsymbol{\mu g} / \mathbf{m l})$ & $\begin{array}{l}\text { Absorbance at } \\
\mathbf{2 9 5} \mathbf{~ n m}\end{array}$ \\
\hline \hline & 0 & 0 \\
\hline \hline & 2 & 0.136 \\
\hline \hline & 4 & 0.2553 \\
\hline \hline & 6 & 0.3794 \\
\hline \hline & 10 & 0.5151 \\
\hline
\end{tabular}

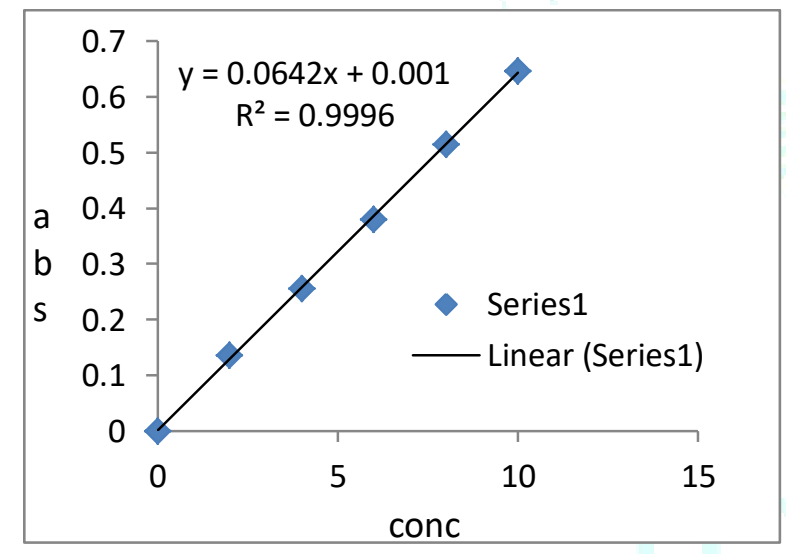

Figure No. 9: Calibration Curve of Telmisartan

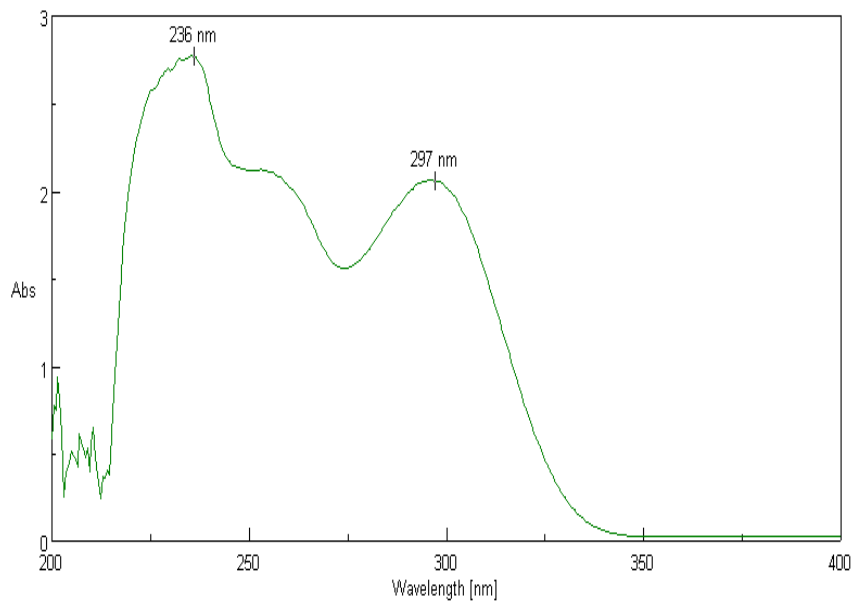

Figure No. 10: UV Spectrum of Telmisartan

Tablet No. 13: UV Parameter for calibration curve in $\mathrm{pH}$ 6.8 buffer solution

\begin{tabular}{|c|c|c|}
\hline Sr.No. & Parameters & $\begin{array}{l}\text { Value in pH } 6.8 \\
\text { phosphate buffer } \\
\text { solution }\end{array}$ \\
\hline 1 & $\begin{array}{l}\text { Absorbance maximum } \\
(\lambda \max ) \text { in } \mathrm{nm}\end{array}$ & $295 \mathrm{~nm}$ \\
\hline 2 & Slope & 0.0642 \\
\hline 3 & Intercept & 0.001 \\
\hline 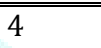 & "Correlation Coefficient & 0.9996 \\
\hline 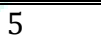 & Equation & $Y=0.0642 X+0.001$ \\
\hline
\end{tabular}

\section{Characterization of Granules of API and Excipients:}

For each type of preliminary formulation blends, blends of API and Excipients were prepared and evaluated for various parameters as explained earlier.

Table No.14: Characterization of Telmisartan Granules :-

\begin{tabular}{|c|c|c|c|c|c|}
\hline \multirow{2}{*}{$\begin{array}{l}\text { Formulation } \\
\text { Batches }\end{array}$} & \multicolumn{5}{|c|}{ Evaluation Parameters } \\
\hline & \begin{tabular}{ll|} 
Angle & of \\
Repose & \\
\end{tabular} & $\begin{array}{l}\text { Bulk Density } \\
\left(\mathrm{gm} / \mathrm{cm}^{3}\right)\end{array}$ & $\begin{array}{l}\text { Tapped } \\
\text { Density } \\
\left(\mathrm{gm} / \mathrm{cm}^{3}\right)\end{array}$ & $\begin{array}{l}\text { Compressibility } \\
\text { Index (\%) }\end{array}$ & $\begin{array}{l}\text { Hausner } \\
\text { Ratio }\end{array}$ \\
\hline F1 & 27.490 & 0.67 & 0.75 & 10.66 & 1.11 \\
\hline F2 & $24.73^{0}$ & 0.72 & 0.79 & 8.86 & 1.09 \\
\hline F3 & $25.33^{0}$ & 0.75 & 0.83 & 9.63 & 1.10 \\
\hline F4 & 25.690 & 0.77 & 0.81 & 4.93 & 1.05 \\
\hline F5 & $27.35^{0}$ & 0.69 & 0.75 & 8.00 & 1.08 \\
\hline F6 & $25.37^{2}$ & 0.76 & 0.82 & 7.31 & 1.070 \\
\hline F7 & $26.23^{0}$ & 0.78 & 0.84 & 7.14 & 1.076 \\
\hline F8 & $24.82^{0}$ & 0.66 & 0.72 & 8.33 & 1.09 \\
\hline F9 & $26.47^{0}$ & 0.70 & 0.75 & 6.66 & 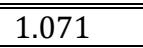 \\
\hline F10 & $25.84^{0}$ & 0.71 & 0.78 & 8.97 & 1.09 \\
\hline F11 & 26.770 & 0.75 & 0.80 & 6.25 & 1.06 \\
\hline
\end{tabular}


Table No.15:- Characterization of Teneligliptin Granules :-

\begin{tabular}{|c|c|c|c|c|c|}
\hline \multirow{2}{*}{$\begin{array}{l}\text { Formulation } \\
\text { Batches }\end{array}$} & \multicolumn{5}{|c|}{ Evaluation Parameters } \\
\hline & $\begin{array}{l}\text { Angle of } \\
\text { Repose }\end{array}$ & $\begin{array}{l}\text { Bulk Density } \\
\left(\mathrm{gm} / \mathrm{cm}^{3}\right)\end{array}$ & $\begin{array}{l}\text { Tapped Density } \\
\left(\mathrm{gm} / \mathrm{cm}^{3}\right)\end{array}$ & $\begin{array}{l}\text { Compressibility } \\
\text { Index (\%) }\end{array}$ & $\begin{array}{l}\text { Hausner } \\
\text { Ratio }\end{array}$ \\
\hline$\overline{\text { F1 }}$ & $25.39^{0}$ & 0.63 & 0.68 & 7.35 & 1.07 \\
\hline$\overline{\mathrm{F} 2}$ & $22.46^{0}$ & 0.65 & 0.71 & 8.45 & 1.09 \\
\hline F3 & $24.85^{0}$ & 0.71 & 0.75 & 5.33 & 1.05 \\
\hline F4 & $23.49^{0}$ & 0.72 & 0.77 & 6.4 & 1.06 \\
\hline F5 & $25.15^{0}$ & 0.68 & 0.70 & 2.85 & 1.02 \\
\hline F6 & $26.61^{0}$ & 0.75 & 0.79 & 5.06 & 1.05 \\
\hline F7 & $23.53^{0}$ & 0.66 & 0.73 & 9.58 & 1.10 \\
\hline F8 & $24.11^{0}$ & 0.64 & 0.69 & 7.24 & 1.07 \\
\hline F9 & $22.36^{0}$ & 0.69 & 0.75 & 8.00 & 1.08 \\
\hline F10 & $22.56^{0}$ & 0.71 & 0.76 & 6.57 & 1.07 \\
\hline F11 & $23.53^{0}$ & 0.70 & 0.77 & 9.09 & 1.10 \\
\hline
\end{tabular}

\section{$>$ Evaluation of Compressed Tablets:}

All the tablet formulation were subjected for Organoleptic, Physical and Chemical evaluation as shape. Thickness, Hardness, Friability, Weight Variation, In-vitro Disintegration Time, Drug Content, And In-vitro Dissolution Studies.

Table No.16: Evaluation of Formulated Batches

\begin{tabular}{|c|c|c|c|c|c|}
\hline $\begin{array}{l}\text { Sr. } \\
\text { No. }\end{array}$ & Formulations & $\begin{array}{l}\text { Thickness } \\
(\mathrm{mm} \pm \mathrm{SD})\end{array}$ & $\begin{array}{l}\text { Hardness } \\
\left(\mathrm{kg} / \mathrm{cm}^{2}\right)\end{array}$ & $\begin{array}{l}\text { Friability } \\
\text { (\%) }\end{array}$ & $\begin{array}{l}\text { Weight Variation (mg } \pm \\
\text { SD) }\end{array}$ \\
\hline 1 & F1 & 3.49 & 4.23 & 0.57 & $497 \pm 0.75$ \\
\hline 2 & $\mathrm{~F} 2$ & 3.30 & 4.45 & 0.45 & $499 \pm 0.50$ \\
\hline 3 & F3 & 3.25 & 4.67 & 0.61 & $498 \pm 0.75$ \\
\hline 4 & F4 & 3.29 & 4.98 & 0.71 & $4496 \pm 0.50$ \\
\hline 5 & F5 & 3.75 & 5.19 & 0.41 & $491 \pm 0.75$ \\
\hline 6 & F6 & 3.43 & 4.71 & 0.67 & $499 \pm 0.50$ \\
\hline 7 & F7 & 3.37 & 4.55 & 0.83 & $501 \pm 0.50$ \\
\hline 8 & F8 & 3.63 & 5.10 & 0.57 & $495 \pm 0.75$ \\
\hline 9 & F9 & 3.26 & 4.81 & 0.91 & $503 \pm 0.75$ \\
\hline 10 & F10 & 3.88 & 4.38 & 0.48 & $4492 \pm 0.50$ \\
\hline 11 & F11 & 3.54 & 4.73 & 0.84 & $498 \pm 0.50$ \\
\hline
\end{tabular}

Table No.17: Evaluation of Post-Formulated Batches

\begin{tabular}{|c|c|c|c|c|c|c|}
\hline Sr. No & Formulations & $\begin{array}{l}\text { Diameter } \\
(\mathrm{mm} \pm \mathrm{SD})\end{array}$ & $\begin{array}{l}\text { Disintegration } \\
\text { Time (min.) }\end{array}$ & \multicolumn{2}{|c|}{ \% Drug Content } & $\begin{array}{l}\text { \% Drug Release in } \\
\text { (420 mins.) }\end{array}$ \\
\hline \multirow[t]{2}{*}{$\overline{11}$} & \multirow[t]{2}{*}{ F1 } & \multirow[t]{2}{*}{$10 \pm 0.00$} & \multirow[t]{2}{*}{62 min } & $\begin{array}{l}\text { Teneligliptin } \\
\end{array}$ & 96.13 & 23.2 \\
\hline & & & & Telmisartan & 95.20 & 20.53 \\
\hline \multirow[t]{2}{*}{2} & \multirow[t]{2}{*}{$\overline{\mathrm{F} 2}$} & \multirow{2}{*}{$10 \pm 0.00$} & \multirow[t]{2}{*}{$71 \mathrm{~min}$} & $\begin{array}{l}\text { Teneligliptin } \\
\end{array}$ & 97.48 & 19.03 \\
\hline & & & & Telmisartan & 95.63 & 14.70 \\
\hline \multirow[t]{2}{*}{3} & \multirow[t]{2}{*}{ F3 } & \multirow[t]{2}{*}{$10 \pm 0.00$} & \multirow[t]{2}{*}{$76 \mathrm{~min}$} & Teneligliptin & 96.32 & 35.61 \\
\hline & & & & Telmisartan & 96.65 & 27.32 \\
\hline \multirow[t]{2}{*}{4} & \multirow[t]{2}{*}{ F4 } & \multirow[t]{2}{*}{$10 \pm 0.00$} & \multirow[t]{2}{*}{87 mins } & Teneligliptin & 97.23 & 22.65 \\
\hline & & & & Telmisartan & 96.35 & 15.32 \\
\hline \multirow[t]{2}{*}{5} & \multirow[t]{2}{*}{ F5 } & \multirow[t]{2}{*}{$10 \pm 0.00$} & \multirow[t]{2}{*}{69 mins } & Teneligliptin & 98.75 & 23.78 \\
\hline & & & & Telmisartan & 99.27 & 18.55 \\
\hline \multirow[t]{2}{*}{6} & \multirow[t]{2}{*}{ F6 } & \multirow[t]{2}{*}{$10 \pm 0.00$} & \multirow[t]{2}{*}{110 mins } & Teneligliptin & 98.58 & 49.45 \\
\hline & & & & Telmisartan & 98.72 & 433.81 \\
\hline \multirow[t]{2}{*}{7} & \multirow[t]{2}{*}{ F7 } & \multirow[t]{2}{*}{$10 \pm 0.00$} & \multirow[t]{2}{*}{79 mins } & Teneligliptin & 96.54 & 29.05 \\
\hline & & & & Telmisartan & 96.23 & 25.30 \\
\hline \multirow[t]{2}{*}{8} & \multirow[t]{2}{*}{ F8 } & \multirow[t]{2}{*}{$10 \pm 0.00$} & \multirow[t]{2}{*}{115 mins } & Teneligliptin & 95.81 & 38.28 \\
\hline & & & & Telmisartan & 96.75 & 31.10 \\
\hline \multirow[t]{2}{*}{9} & F9 & $10 \pm 0.00$ & 92 mins & Teneligliptin & 97.38 & 23.48 \\
\hline & & & & Telmisartan & 96.87 & 19.42 \\
\hline$\overline{10}$ & F10 & $10 \pm 0.00$ & 107 mins & Teneligliptin & 98.41 & 42.41 \\
\hline & & & & Telmisartan & 99.15 & 40.48 \\
\hline$\overline{11}$ & F11 & $10 \pm 0.00$ & 96 mins & Teneligliptin & 97.36 & 15.88 \\
\hline & & & & Telmisartan & 96.25 & 10.96 \\
\hline
\end{tabular}


Table No.18: Comparative \%Drug Release of Bathes (Teneligliptin)

\begin{tabular}{|l|l||l||l||l|l||l||l|l||l||l||l||l||}
\hline Sr. No. & Time (min) & F1 & F2 & F3 & F4 & F5 & F6 & F7 & F8 & F9 & F10 & F11 \\
\hline \hline 1 & 0 & 0 & 0 & 0 & 0 & 0 & 0.00 & 0 & 0 & 0 & 0 & 0 \\
\hline \hline 2 & 60 & 4.46 & 2.74 & 10.16 & 3.55 & 3.74 & 13.48 & 5.29 & 11.23 & 2.28 & 12.56 & 2.64 \\
\hline 3 & 120 & 7.23 & 5.39 & 16.21 & 6.88 & 7.35 & 18.02 & 8.36 & 16.22 & 5.27 & 19.87 & 3.45 \\
\hline \hline 4 & 180 & 10.45 & 8.36 & 20.23 & 10.51 & 10.54 & 25.20 & 12.87 & 20.65 & 9.34 & 24.54 & 5.36 \\
\hline 5 & 240 & 13.81 & 11.65 & 24.41 & 13.06 & 12.54 & 31.69 & 15.32 & 25.17 & 12.36 & 29.36 & 8.74 \\
\hline \hline 6 & 300 & 17.35 & 14.98 & 27.87 & 15.56 & 15.67 & 38.56 & 21.36 & 29.34 & 15.23 & 33.45 & 11.54 \\
\hline 7 & 360 & 20.15 & 17.05 & 31.56 & 19.32 & 19.65 & 43.76 & 27.65 & 33.54 & 18.65 & 38.54 & 13.65 \\
\hline \hline 8 & 420 & 23.35 & 19.03 & 35.61 & 22.65 & 23.78 & 49.45 & 29.05 & 38.28 & 23.48 & 42.41 & 15.88 \\
\hline
\end{tabular}

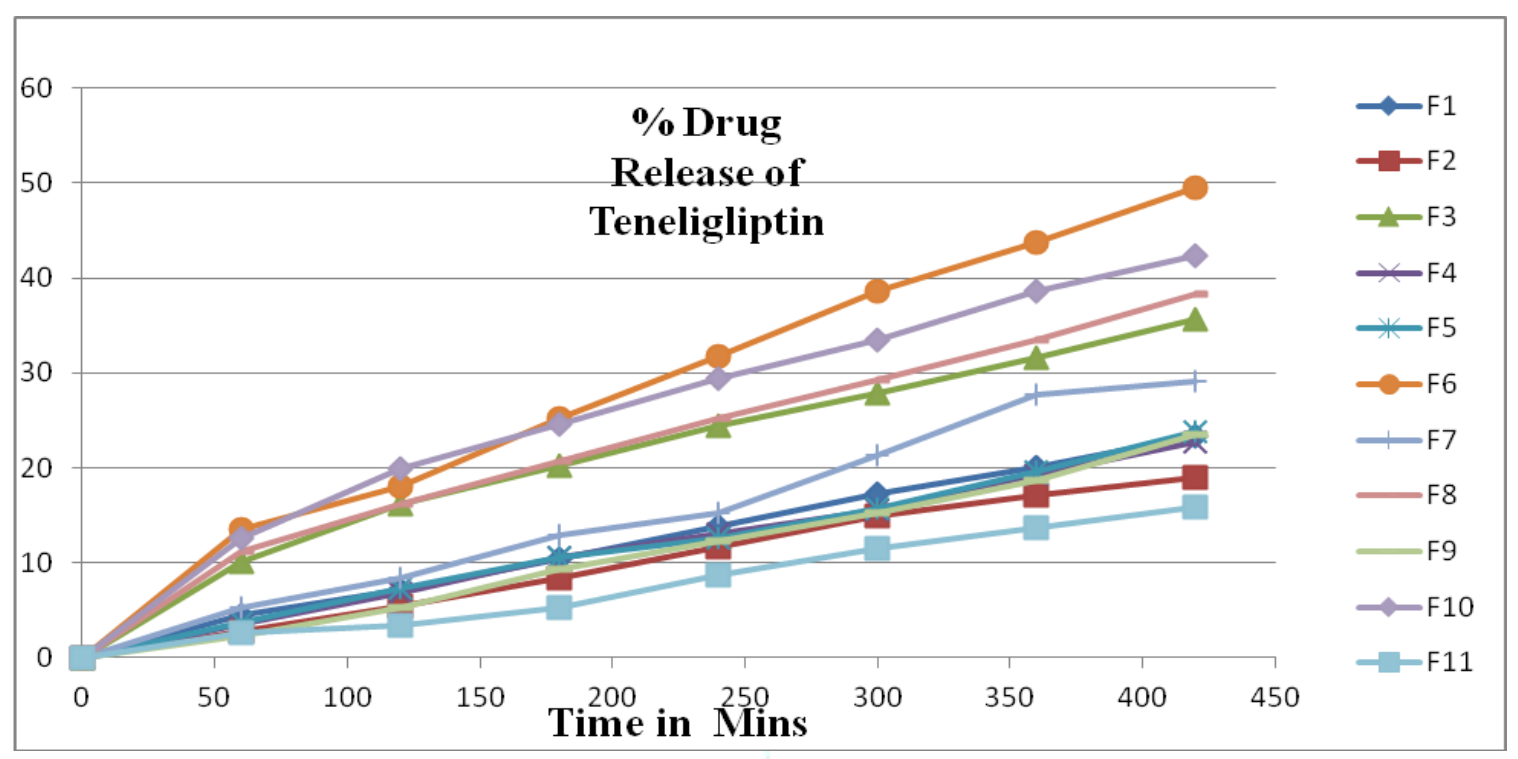

Figure No.11 : Comparative Dissolution Profile of All Batches (Teneligliptin)

Table No.19: Comparative \%Drug Release of Bathes (Telmisartan)

\begin{tabular}{|c|c|c|c|c|c|c|c|c|c|c|c|c|}
\hline Sr. No. & $\begin{array}{l}\text { Time } \\
\text { (min.) }\end{array}$ & F1 & F2 & F3 & F4 & F5 & F6 & F7 & F8 & F9 & F10 & F11 \\
\hline 0 & 0 & 0 & 0 & 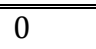 & 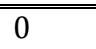 & 0 & 0.00 & 0 & 0 & 0 & 0 & 0 \\
\hline $\bar{~} 1$ & 60 & 5.23 & (1.2 & 5.79 & 2.87 & 0.77 & 7.62 & 2.63 & 9.25 & 3.96 & $\begin{array}{l}13.48 \\
\end{array}$ & 0.89 \\
\hline 3 & 120 & 8.66 & 3.7 & 9.52 & 4.98 & 2.37 & 11.06 & 5.98 & 13.65 & 5.47 & 19.56 & 1.23 \\
\hline 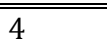 & ב180 & 111.56 & 5.5 & 13.85 & 7.22 & $\bar{~} 5.56$ & "16.71 & 9.23 & 18.36 & 8.56 & 24.32 & 2.84 \\
\hline$\overline{5}$ & 240 & 14.25 & 7.4 & 17.69 & 9.36 & 8.74 & 23.28 & $\begin{array}{l}12.34 \\
\end{array}$ & 20.96 & $\begin{array}{l}11.91 \\
\end{array}$ & 29.89 & 3.95 \\
\hline 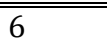 & 300 & 16.32 & 9.8 & 21.54 & 11.87 & 11.54 & 29.63 & 17.36 & 24.38 & 14.21 & 34.13 & 6.26 \\
\hline 7 & 360 & 18.58 & 1212.6 & 24.35 & "13.21 & 15.23 & 37.96 & 21.03 & 28.36 & 16.69 & 37.33 & 8.45 \\
\hline 8 & 4420 & 20.53 & $\begin{array}{l}14.7 \\
\end{array}$ & 27.32 & "15.32 & 18.55 & "43.81 & 25.3 & 31.1 & 19.42 & "40.48 & 10.96 \\
\hline
\end{tabular}




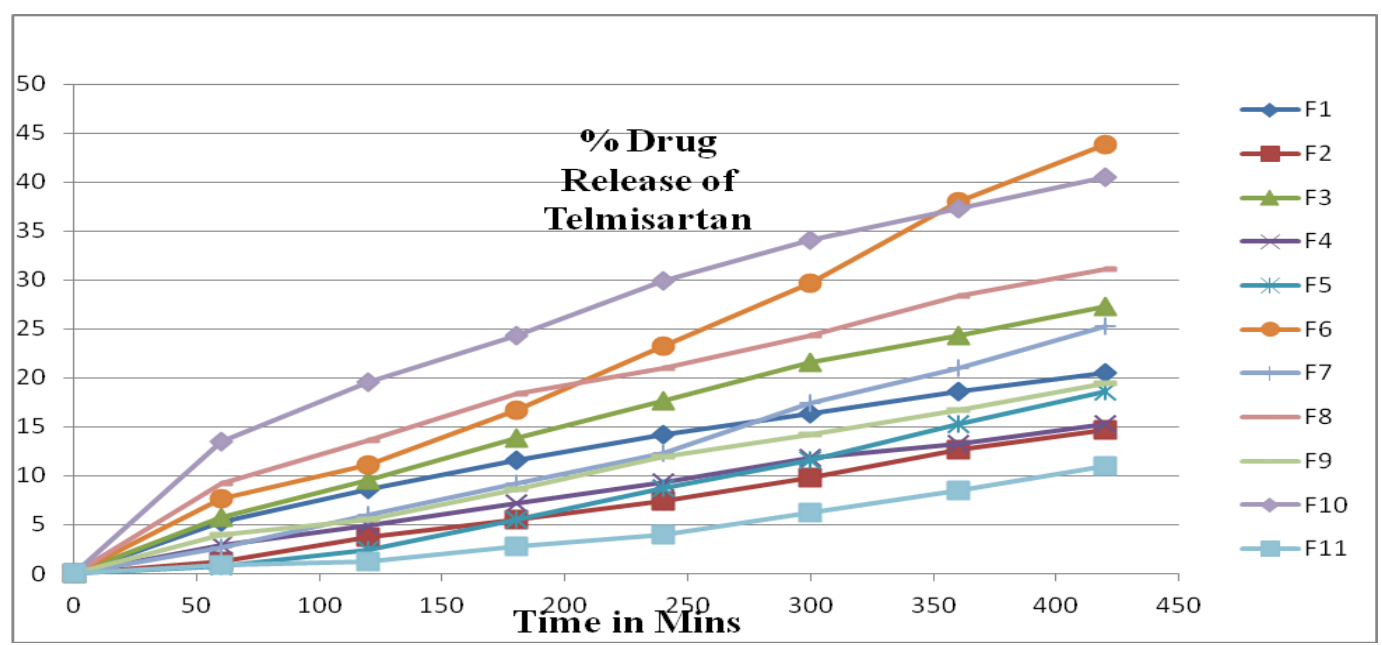

Figure No.12: Comparative Dissolution Profile of All Batches (Telmisartan)

\section{$>$ Stability Study:}

Stability studies of the Best Formulation F6 was carried out by keeping the tablets at room temperature and $40^{\circ} \mathrm{C} \pm 2^{\circ} \mathrm{C} /$ $75 \pm 5 \%$ RH (stability chamber) for 30 days. From the stability studies it was found that formulation were stable at room temperature and $40^{\circ} \mathrm{C} \pm 2^{\circ} \mathrm{C} / 75 \pm 5 \% \mathrm{RH}$ for a period of 60 days. There was no appreciable and highlighting change in physical properties, drug release and drug content during the testing period. Thus the test indicated stability of formulations.

\section{Physical Appearance:}

Color: unchanged. Odour: unchanged

Table No. 20: Stability Parameters of F6 for 0, 30, 60 Days

\begin{tabular}{|c|c|c|c|c|c|}
\hline Formulations & $\begin{array}{l}\text { Study } \\
\text { Conditions } \\
\text { Specification }\end{array}$ & Months & Drugs Name & $\begin{array}{l}\% \text { Drug } \\
\text { Content }\end{array}$ & $\begin{array}{ll}\% & \text { Drug } \\
\text { Release } & \end{array}$ \\
\hline \multirow[t]{6}{*}{ F6 } & \multirow{6}{*}{$\begin{array}{l}40^{\circ} \mathrm{C} \pm 2^{0} \mathrm{C} / 75 \\
\pm 5 \% \mathrm{RH}\end{array}$} & \multirow[t]{2}{*}{ Initial } & Teneligliptin & 98.58 & 499.45 \\
\hline & & & Telmisartan & 98.72 & 43.81 \\
\hline & & \multirow[t]{2}{*}{30 days } & Teneligliptin & 98.21 & 48.64 \\
\hline & & & Telmisartan & 98.44 & "42..37 \\
\hline & & \multirow[t]{2}{*}{ 60days } & Teneligliptin & 97.73 & 47.58 \\
\hline & & & "Telmisartan & 97.84 & 41.46 \\
\hline
\end{tabular}

\section{$>$ Biological screening}

Animal study:-

Table No.21:- Body weight of albino rats before and after treatment:-

\begin{tabular}{|c|c|c|}
\hline Sr.No & Body wt. before treatment & Body wt. after end of the treatment \\
\hline Negative Control & $241 \pm 1.40$ & $229 \pm 1.63$ \\
\hline Positive Control & $240 \pm 1.44$ & $242 \pm 1.67$ \\
\hline Std & $220 \pm 1.88$ & $210 \pm 1.78$ \\
\hline 4a & $260 \pm 2.45$ & $255 \pm 2.56$ \\
\hline 4b & $250 \pm 2.76$ & $262 \pm 2.67$ \\
\hline 4c & $250 \pm 1.78$ & $270 \pm 2.78$ \\
\hline
\end{tabular}


Table no. 22:- Blood glucose level

\begin{tabular}{|l||l||l|l|l|l||}
\hline \multirow{2}{*}{ Drug } & \multicolumn{5}{|c|}{ Blood glucose level mg/dl (Mean \pm SEM) } \\
\cline { 2 - 6 } & 0 days & 2 days & 4 days & 6 days & 8 days \\
\hline \hline Negative control & $232 \pm 2.31$ & $233 \pm 2.97$ & $231 \pm 1.24$ & $233 \pm 2.86$ & $230 \pm 2.46$ \\
\hline \hline Positive control & $115 \pm 1.44$ & $116 \pm 2.67$ & $118 \pm 1.45$ & $114 \pm 2.45$ & $115 \pm 2.45$ \\
\hline \hline Standard & $204 \pm 2.28$ & $118 \pm 2.21$ & $153 \pm 1.99$ & $128 \pm 2.27$ & $116 \pm 1.51$ \\
\hline \hline 4a & $215 \pm 4.55$ & $190 \pm 4.78$ & $151 \pm 1.23$ & $137 \pm 1.90$ & $119 \pm 3.64$ \\
\hline \hline $4 \mathrm{~b}$ & $205 \pm 3.54$ & $194 \pm 2.67$ & $162 \pm 2.89$ & $133 \pm 1.43$ & $128 \pm 3.51$ \\
\hline \hline 4c & $222 \pm 1.89$ & $203 \pm 1.78$ & $157 \pm 2.45$ & $142 \pm 1.97$ & $130 \pm 1.09$ \\
\hline \hline
\end{tabular}

The antidiabetic activity is held and by the observation of blood glucose levels we can say that the Teneligliptin and Telmisartan Combination is useful in the activity.

\section{CONCLUSION:}

On the basis of the study, selection of drug candidate and the type of formulation lead to the formulation of Bilayer Tablets to treat Co-existent Type II Diabetes Mellitus and Hypertension were formulated successfully. The addition of magnesium stearate which produce satisfactory results for flow property of powders. Addition of crospovidone improved drug release of Telmisartan layer. The Preformulation study revealed the purity of drug and also it confirmed the stability of drug with excipient hence proved to be compatible there.

All the tablet formulations showed satisfactory results with respect to hardness, friability, disintegration time, drug content and In-vitro dissolution studies. The binder, filler, diluents, lubricants used in the formulations which improve the tablet quality and sustained release agent improve the disintegration and dissolution property of tablets. The powder was granulated by wet granulation and the second layer was compressed above the compressed first layer, it is a good method used for the compression of bilayer tablets. Wet granulation is the best method for formulation of such bilayer tablets. The results obtained in Biological Studies revealed that the present drug combination shows antidiabetic activity. Telmisartan does not hinders the antidiabetic activity of Teneligliptin when taken in combination. Thus, there is no Drug-Drug Interaction between Teneligliptin and Telmisartan. Therefore, this research work concludes the successful was shown the "Formulation and Evaluation of Teneligliptin and Telmisartan Bilayer Tablets for the Treatment of Coexistent Type II Diabetes Mellitus and Hypertension".

\section{ACKNOWLEDGEMENT}

The authors are thankful to the principal and management of Dr. Vithalrao Vikhe Patil College of Pharmacy, for providing necessary facilities to carry out this work.

\section{CONFLICT OF INTERESTS}

Declared none.

\section{REFERENCES}

1. Nisharani Ranpise, Preeti Jamkar, Harshada Langote, "Formulation and Development of Fixed Dose Combination of Antihypertensive and Antidiabetic Agent for treatment of Coexistent Type Two Diabetes Mellitus and Hypertension", Indian Journal of Pharmaceutical Education and Research, Vol 48, Issue Suppl, Oct-Dec, 2014
2. Ganesh R. Godge Varsha D. Palwe, Pratap Y. Pawar, "Formulation Development and in vitro Evaluation of Sustained Release Tablets of Telmisartan by Solid Dispersion Technology, Asian Journal of Pharmaceutical Technology \& Innovation, Issue04 (17); 2016; Page No. 131 - 139

3. Manish Maladkar, Srividya Sankar, Kushal Kamat, "Teneligliptin: Heralding Change in Type 2 Diabetes", Journal of Diabetes Mellitus, 2016, Issue 6, Page No. 113-131.

4. Venkateswara Rao. S, Rodhay. G \& Padmalatha. K, "Design and evaluation of mouth dissolving tablets of telmisartan by using different super disintegrants", Indo American Journal of Pharmaceutical Research, 2017, Vol 7 Issue 09, 2017. ISSN NO: 2231-6876

5. Sri Harsha Tella \& Marc S Rendell, DPP-4 inhibitors: focus on safety Expert Opin. Drug Saf. (2014) 14(1)

6. Rohan D. Deshpande, D. V. Gowda 1, Nawaz Mahammed and Deepak N. Maramwar ,Bi-Layer Tablets - An Emerging Trend: A Review, International Journal of Pharmaceutical sciences and research, 2011, Vol. 2(10), 2534-2544.

7. Mogili Vijaya Krishna, T. Venkateswara Rao, "Formulation and Evaluation of Multilayered Tablets of Metformin, Telmisartan and Glipizide for the Combination Therapy of Diabetes and Hypertension, World Journal of Pharmacy and Pharmaceutical Sciences, Volume 3, Issue 11, 1116-1135.

8. Venugopal K, M. Z. Mohammed, Prevalence of hypertension in type-2 diabetes

Mellitus, CHRISMED Journal of Health and Research, Vol 1, Issue 4, Oct-Dec 2014, 223-227

9. Piyush Agarwal, Chhavi Jindal, Vinayak Sapakal, "Efficacy and Safety of Teneligliptin in Indian Patients with Inadequately Controlled Type 2 Diabetes Mellitus: A Randomized, Double-blind Study", Indian Journal of Endocrinology and Metabolism, Volume 22, Issue 1, January-February 2018.

10. Manish Patil, Harsha D Jani, Suleman S Khoja, Narmin A Pirani, Shamim S Khoja, "A Review on chemistry and pharmacological activity of metformin hydrochloride and teneligliptin hydrobromide hydrate in combined dosage form", Vol. 5, Issue 3, magazine.pharmatutor.org, Pg no: 24-30.

11. Patel H., Shah v., Upadhyay u., "New Pharmaceutical Excipient in Solid Dosage Forms-A Review", International Journal of Pharmacy and Life Sciences, 2011; 2 (8): 1006-1019.

12. Nisharani Ranpise, Preeti Jamkar, Harshada Langote, "Do Fixed Dose Combinations Play an Important Role in the Management of Coexistent Type Two Diabetes Mellitus and Hypertension?", Indian Journal of Pharmaceutical Education and Research, Vol 49, Issue 3, Jul-Sep, 2015, 190-199.

13. Chandra Narayan Gupta, Vijay Raghavan, Sukanta Sen, Sanjay Kothari, Role of teneligliptin in rural India as add-on third drug in patients with type 2 diabetes mellitus, International Journal of Advances in Medicine, April 2017; 4 Edition, Issue 2: Pg. No. :401-405.

14. Modi Foram P., Patel Priyal R., Formulation, Optimization \& Evaluation of Fixed Dose Combination Moisture Barrier Film Coated Bilayer Tablet of Artesunate \& Amodiaquine Hydrochloride, International Journal of PharmTech Research CODEN (USA): IJPRIF, Vol.3, Issue No.4, Oct-Dec 2011, Pg. No.: 2124-2134. 
15. Fred J. Bandelin, "Compressed Tablet by Wet Granulation" In: Liberman H.A. Lachman L. Schwartz J.B, Pharmaceutical Dosage Form; Tablets, New York 2 ${ }^{\text {nd }}$ Edition, 1989; Vol-1:604-620.

16. Vinit Chavhan, Rohini lawande, Jyoti Salunke, Minal Ghante, Supriya Jagtap, “U.V. Spectrophotometric Method Development and Validation for Telmisartan in Bulk and Tablet Dosage Form", Asian Journal of Pharmaceutical and Clinical Research, Volume 6 issue 4, 2013, 19-21.

17. Amit M. Sonawane, Kiran K. Dhokale, Varsha A. Randhe, "A Simple. U.V.- Spectrophotometric Method Development and Validation of Teneligliptin in Tablet Dosage Form. Indo American Journal of Pharmaceutical Research, 2016 Vol 6, Issue 04, 2016, issn no: 2231-6876

18. Raghavendra K kumar Gunda, Prasada Rao Manchineni, Design, Formulation and In Vitro Evaluation of Telmisartan Sustained Release Tablets, Mintage Journal of Pharmaceutical \& Medical Sciences, Vol 7, Suppl 3, 2018, 22-27.

19. Kimberley Jackson, David Young and Sonia Pant, "DrugExcipient Interactions and their Affect on Absorption.", PSTT Vol. 3, No. 10 October 2000, 336-345.

20. Lenzen S. "The mechanisms of alloxanandstreptozotocininduced diabetes".Diabetologia 2008; 51:216-26.
21. Goldner MG, Gomori G. "Studies on the mechanism of alloxan diabetes". Endocrinology1944; 35:241-8.

22. Banerjee S, Bhattacharya G. "Studies on the mechanism of alloxanhypoglycemia”. JBiolChem1948; 175:923-8.

23. Banerjee S. "On the hypoglycemic action of alloxan". J BiolChem 1945; 158:547-50.

24. M. Ramanathan and N. Venkatesan, "Biological Screening Procedures For Antidiabetic Drugs- A Review", World Journal of Pharmacy and Pharmaceutical Sciences, Volume 6, Issue 10, 191-204.

25. Report on the Deliberation Results, April 27, 2012; Evaluation and Licensing Division, Pharmaceutical and Food Safety Bureau, Ministry of Health, Labour and Welfare; Brand name: Tenelia Tablets $20 \mathrm{mg}$, Non-proprietary name: Teneligliptin Hydrobromide Hydrate (JAN), Applicant Mitsubishi Tanabe Pharma Corporation, Date of application: August 26, 2011.

26. Dominik Wincewicz, Jan J. Braszko, Telmisartan attenuates cognitive impairment caused by chronic stress in rats, Pharmacological Reports, Issue No. 66, Year 2014, Pg. No. 436441. 